\title{
Erratum: Optimal feedback control successfully explains changes in neural modulations during experiments with brain-machine interfaces
}

\author{
Frontiers Production Office * \\ Frontiers Production Office, Frontiers, Lausanne, Switzerland
}

Keywords: brain-machine interfaces, neural modulations, optimal feedback control, computational motor control, process noise

OPEN ACCESS

Approved by: Neuroscience Editorial Office, Frontiers, Switzerland

*Correspondence: Frontiers Production Office, production.office@frontiersin.org

Received: 18 September 2015 Accepted: 18 September 2015 Published: 29 September 2015

Citation: Frontiers Production Office (2015) Erratum: Optimal feedback control successfully explains changes in neural modulations during experiments with brain-machine interfaces.

Front. Syst. Neurosci. 9:137. doi: 10.3389/fnsys.2015.00137

\section{An erratum on}

Optimal feedback control successfully explains changes in neural modulations during experiments with brain-machine interfaces

by Benyamini, M., and Zacksenhouse, M. (2015). Front. Syst. Neurosci. 9:71. doi: 10.3389/fnsys.2015.00071

Reason for Erratum:

Due to a typesetting error, the reviewer Frédéric Crevecoeur was inadvertently removed from the final published article. The publisher apologizes for this mistake.

This error does not change the scientific conclusions of the article in any way.

The original article has been updated.

Copyright $(0) 2015$ Frontiers Production Office. This is an open-access article distributed under the terms of the Creative Commons Attribution License (CC BY). The use, distribution or reproduction in other forums is permitted, provided the original author(s) or licensor are credited and that the original publication in this journal is cited, in accordance with accepted academic practice. No use, distribution or reproduction is permitted which does not comply with these terms. 